\title{
Dr. J. W. Ker Succeeds Dean Gibson at U.N.B.
}

In July, 1961, John William Ker will leave the University of British Columbia for the University of New Brunswick where he will succeed Dean J. M. Gibson who is retiring after many years of distinguished service.

John (Jack) Ker was born in Chilliwack, B.C. in 1915. He is married and has three children.

Dr. Ker has three degrees: B.A.Sc. (Forest Engineering) (Honours) Brit. Col., 1941; M.F., Yale, 1951; D.F. Yale, 1957. His primary academic interests have been in the fields of mensuration, statistics, and economics.

John served as a Forest Ranger in the B.C. Forest Service 1941-1945. From 1945-1948 he was engaged in research in forest mensuration for the B.C. Forest Service at Victoria. In 1948 he joined the University of British Columbia as an Assistant Professor. In 1953 he became Associate Professor and has assumed many administrative responsibilities in addition to a heavy teaching load at both undergraduate and graduate levels. Dr. Ker served as Graduate Program Director, Chairman of the Forest Research Committee, and Associate Director of the University Research Forest in addition to participation in several general University committees and service in Professional groups. John was Chairman of the Vancouver Section of the C.I.F. in 1956-57. He worked on behalf of the Association of British Columbia Foresters as Member of the Board of Examiners in 1954, as Chairman of the Board of Examiners in 1955 and as Member of Council in 1956. He is a member of the Society of American Foresters and will present a paper at the joint S.A.F. C.I.F. meeting at Minneapolis in October.

Dr. Ker is author or co-author of thirty publications in the fields of mensuration and economics. He has been employed as a consultant by several British Columbia companies and by the Northern Interior Lumber Manufacturers Association.

In spite of his heavy commitments in academic life, Jack and his wife Marguerite have taken an active part in community affairs. Mrs. Ker was one of the originators of the idea of the Vancouver C.I.F. Wives group which is discussed under Section News.

Former students, associates in the U.B.C. Faculty of Forestry, and many friends throughout the University and the Community will miss the Ker family sincerely and will join with us in wishing them happiness and success at the University of New Brunswick.

\section{Accident Prevention}

Third year forestry students from the University of British Columbia taking 21 days of intensive field work at U.B.C.'s 10,000-acre research forest at Haney, B.C. were a well protected lot-thanks to McCulloch of Canada, manufacturers of chain saws.

When the camp opened Mr. A. R. W. Campbell, field representative for the company, presented each student with a safety hat. The presentation, he 